\title{
Anti-Stroke Exercise Decreases Blood Pressure in Elderly with Hypertension
}

\author{
Erna Dwi Wahyuni, Ika Nur Pratiwi, Kurnia Fidyastria \\ Faculty of Nursing, UniversitasAirlangga \\ Surabaya, Indonesia \\ email: erna-d-w@fkp.unair.ac.id
}

\begin{abstract}
Hypertension is a serious health problem because the high number of morbidity and mortality. Generally, the treatments of hypertension throughout two ways, pharmacological and non-pharmacological. Anti-stroke exercise was the one of non-pharmacological therapy that is recommended for hypertension. The study aimed to identify the effect of anti-stroke exercise on blood pressure in elderly with hypertension. The study was a pre-experimental with one group pre-posttest design. There were 19 out of 36 elderlies taken as respondents by purposive sampling. Independent variable was anti-stroke exercise and dependent variable was systolic blood pressure. This study analyzed by paired sample t-test. There was difference between pre- and post-test on systolic pressure $(p=0.000)$. Anti-stroke exercise which consists of three phases: warming, core, and cooling, had influence to decrease blood pressure in elderly. Nurses may applied anti-stroke exercise as non-pharmacological therapies to decrease elderly's blood pressure with hypertension. Further research needs to explore more throughout develop the research design and expanding the samples.
\end{abstract}

Keywords- blood pressure, anti-stroke exercise, elderly, hypertension

\section{INTRODUCTION}

Hypertension is an increase in systolic blood pressure $\geq 140$ $\mathrm{mmHg}$ and diastolic blood pressure $\geq 90 \mathrm{mmHg}$ diagnosed by an examination on a regular basis, at least three times the examination.[1] The risk factor that lead to high blood pressure are age, gender, obesity, lack of physical activity and others.[2] Increasing age causes a blood pressure increase, it happens because there is a decline in physical, psychological, and biochemical responses in the body ability during aging process, which can lead to degenerative diseases such as hypertension.[3] The elderly population in Indonesia reaches to 20,24 million people, it is equal at $8,03 \%$ of the entire population in 2014. [4] The more increasing number of elderly population in Indonesia, the more morbidity degenerative diseases, which is hypertension. Therefore, it is necessary to prevent hypertension and its complications.

Hypertension treatment can be done through two ways, namely: pharmacological and non-pharmacological. Exercise is one of non-pharmacological therapies that can be recommended for patients with hypertension.[5] One exercise which can be recommended is an anti-stroke exercise. Anti stroke exercise with moderate intensity can be used as a therapy for the elderly with hypertension. [6]

According to reference [7], cardiovascular disease is the first killer in the world for over 45 years and it is estimated 12 million people die each year. Hypertension di considered as the main cause of death, around 7,5 million or approximately $12,8 \%$ of the total deaths. In Indonesia, hypertension is the third cause of death after stroke and tuberculosis, which the former reaches to $6,7 \%$ of death in all age groups[8] One of ten the most dangerous diseases in Surabaya shows that there is an increase of hypertension, which 2011 and 2012 was ranked seventh with $3,3 \%$ and $3,06 \%$ respectively. In 2013, hypertension was ranked second at 13,6\%.[9] Based on previous study at UPTD Griya Wreda Surabaya in October 2016 , there was $46,75 \%$ of elderly with hypertension, the average of systolic blood pressure was $152,23 \mathrm{mmHg}$ and $91,53 \mathrm{mmHg}$ for diastolic. Intervention that have been given were elderly exercise but it was only given once a week, and also giving anti-hypertensive medication in some elderly.

Elderly is experiencing aging, structural and functional on peripheral vascular endothelial system changes. These changes include atherosclerosis and reduction of vascular smooth muscle relaxation. In this condition, there is a decrease of Nitric Oxide (NO) and increase of Radical Oxygen Species (ROS) in the endothelium of blood vessels, causing vasoconstriction more dominant than the vasodilatation of blood vessels, so it can reduce the ability of distension and stretch receptors. Moreover, in patient with hypertension, there is also a decreased baroreceptor sensitivity and increased sympathetic nerve, thereby stimulates the anterior pituitary to secrete ACTH. ACTH secreted can stimulate secretion of catecholamines in drenal medulla which causes an increase in plasma catecholamine concentration affecting the vasoconstriction increase of blood vessels.[10] The impact of long-term hypertension can also cause a sudden death. Therefore, hypertension should be treated.[11]

Based on reference [6] the result indicates that the antistroke exercise is effective in decreasing blood pressure. This study shows there is a significant difference on systolic blood pressure between pre- and posttest $(8,07 \mathrm{mmHg})$ and also diastolic $(4,92 \mathrm{mmHg})$ after doing anti-stroke exercise, this exercise is done every morning for 3 days. The exellence of anti-stroke exercise among other exercises for elderly are more 
accessible, easy to memorize. It also indicates that the antistroke exercise decrease blood pressure. [6]

\section{METHOD}

The study was pre-experimental with one group pre-post test design. The research was conducted at UPTD Griya Wreda Surabaya, starting on.

The independent variable was the anti stroke exercise, as well as the dependent variable was blood pressure. The population were all elderly peple with hypertension at UPTD Griya Wreda Surabaya which are 36 elderly people. Samples were obtained by 19 respondents referring to the inclusion and exclusion criteria using purposive sampling technique.

1. Inclusion criteria were: elderly aged $60-75$ years, did not use means for moving and they were independent in ADL (Katz Index A).

2. Exclusion criteria were: elderly with complication diseases such as renal failure, heart failure, stroke and osteo arthritis.

All respondent were in one group, which were received anti-stroke intervention. Study conducted for 19 days on December 2016 -January 2017. The data were obtained by measuring blood pressure measurement by mercury sphygmomanometer and stethoscope at before and after intervention. Then data was analyze by using paired t-tests, with level of significance $\alpha \leq 0,05$. In addition, this research has passed the ethic review and been certified by Ethical Committee Faculty of Nursing, Universitas Airlangga, Surabaya with Ethical Approval No. 312 - KEPK.

\section{RESULT}

TABLE I.

STATISTICAL RESUlt (PAIRED T TEST)

\begin{tabular}{lllc}
\hline \multirow{2}{*}{ Subject } & \multicolumn{3}{c}{ Systolic Blood Pressure } \\
\cline { 2 - 4 } & \multicolumn{1}{c}{ Pre-test } & Post-test & Pre-post difference \\
\hline Mean & 154.74 & 140.79 & 13.947 \\
Paired t Test & $\mathrm{p}=0.000$ & & \\
\hline
\end{tabular}

Average of systolic blood pressure was $154,74 \mathrm{mmHg}$, while at the post-test, the average of systolic blood pressure was $140,79 \mathrm{mmHg}$. Decrease in blood pressure varies, ranging from $5 \mathrm{mmHg}$ to $25 \mathrm{mmHg}$ with average $13,947 \mathrm{mmHg}$. Paired t-test obtained $\mathrm{p}$ value $=0.000$ which means that there was differences between pre and post in systolic blood pressure (see table 1).

\section{DISCUSSION}

Based on the result of pre-test, the average value of systolic blood pressure was $154,74 \mathrm{mmHg}$ with the highest systolic blood pressure at $180 \mathrm{mmHg}$ and the lowest systolic blood pressure at $140 \mathrm{mmHg}$. This result indicates that the average of the systolic blood pressure was hypertension at 1 degree. However, systolic blood pressure which were done during the post-test data decreased for all samples by a mean value of the post-test at $140.79 \mathrm{mmHg}$. The results of post-test indicates that the average of the systolic blood pressure was hypertension at 1 degrees. Eventhough there was no change in blood presseure level, it shows the average of decrease in systolic blood pressure at 13, $947 \mathrm{mmHg}$. Paired sample t-test $\mathrm{p}$ value $=0.000$ means that the anti-stroke exercise affected to blood pressure decline.

Anti stroke exercise is a moderate-intensity physical activity which is done by tapping the entire extremity, shoulder, back waist and abdomen, preceded by a warming and ended with cooling. These exercise can decrease systolic blood pressure in several ways, which are an increasing release of NO (nitric oxide), arterial stiffness decline, increasing sensitivity to baroresptor, and a reduce in sympathetic activity. Anti stroke exercise increases parasympathetic activity. The parasympathetic nerve will secrete the neurotransmitter acetylcholine (ACh), which causes an increase in the release of Nitric Oxide (NO) endothelium. The increase of Nitric Oxide (NO) endothelium realease leads to reduce arterial stiffness. Nitric Oxide (NO) is also called endothelium Derived Relaxing Factor (EDRF), which is a potential vasodilator causing relaxation of the heart muscle and blood vessels. [12]

In addition, anti stroke exercise mechanism can increase parasympathetic activity that can lead to increase sensitivity of baroresepor, it is caused by the fact that physical activity increases the strength and frequency of repeated stress on the endothelium, thus it can release several factors of endothelium to increase the sensitivity of baroreceptor (Yusuf, et al. 2005). These respond of baroreceptor system was sympathetic activity decreases, which was caused by output inhibit sympathetic. It causes a lower sympathetic outflow to arterioles (decreasing peripheral resistance), a decrease in sympathetic outflow to the vein (decreasing cardiac filling pressures), a decrease in sympathetic tone and increase tone parasympathetic to the heart (holding up the heart rate and reduce contractility), and inhibiting the secretion of $\mathrm{ADH}$, so a decreased blood pressure happens. Besides, decreased sympathetic activity will reduce the production of renin and angiotensin II so it can decrease reabsorption of water, salt reabsorption, vasoconstriction and cardiac contractility.

Moreover, reference [13] found the moderate-intensity physical activity can reduce systolic blood pressure 4-9 $\mathrm{mmHg}$, but this study showed the average decrease in systolic blood pressure from $13,947 \mathrm{mmHg}$ with the smallest decline by 5 $\mathrm{mmHg}$ and the biggest drop by $25 \mathrm{mmHg}$. There was one respondent who has decreased systolic blood pressure of 25 $\mathrm{mmHg}$ consumed $\mathrm{OAH}$, which was Captropil. Captorpril is one of ACE inhibitors. ACE inhibitors aims to reduce systemic vascular resistance, and the average diastolic and systolic blood pressure in hypertensive patients.[14]. A woman aged 71-75 years experienced the lowest decreasing systolic blood pressure by $5 \mathrm{mmHg}$. Reference [15] stated that it would decrease estrogen levels when women enter old age (menopause) so that women are more susceptible to hypertension. Although they were given treatment but the age and gender influence in reducing systolic blood pressure, due to the fact that blood vessels on elderly have passed atherosclerosis and notably, menopause where levels of estrogen hormone will decrease, while the hormone estrogen has a function to increase the production of HDL to protect blood vessels from atherosclerosis. 
According to reference [16], physical exercise can increase HDL, to help metabolism and reduce levels of LDL (Low Density Lipopotein). LDL is the major cause of atherosclerosis. HDL (High Density Lipoprotein) aims to restrain the process of atherosclerosis. HDL has the ability to relocate cholesterol from atheroma within arteries and return it to the liver for secretion and reuse.

Respon from respondent was exellent, about half respondent said that after doing the anti-stroke exercise, their body feels better, and blood pressure may decrease. Respondents were fascinated of being invited to exercises because respondents had no other activities at home.

\section{CONCLUSION AND RECOMMENDATION}

\section{A. Conclusion}

Anti stroke exercise which has been conducted three times a week for 2 weeks with duration of exercise 20 minutes can reduce systolic blood pressure in elderly with hypertension, because exercise can cause blood vessel relaxation and vasodilatation.

\section{B. Recommendation}

The results of this study can be used as a method of novelty and innovation in nursing, especiallygerontic nursing and surgery-medical nursing in providing non-pharmacological therapy for patient with hypertension. A further research can do research on the influence of anti stroke exercise to decrease blood pressure in the elderly with concerning in confounding factor (consumption $\mathrm{OAH}$ ) so that the sample more homogeneous. Furthermore, the next researcher can conduct on more samples or control group.

\section{REFERENCES}

[1] S. J. McPhee and W. F. Ganong, Pathophysiology of Disease: An Introduction to Clinical Medicine. Lange Medical Books/McGraw-Hill,
Medical Pub. Division, 2006.

[2] Y. I. Prasetyaningrum, Hipertensi Bukan Untuk Ditakuti. Jakarta: FMedia, 2014.

[3] U. Nurrahmani, Stop Hipertensi. Yogyakarta: Familia, 2012.

[4] Badan Pusat Statistik, "Statistik Penduduk Lanjut Usia," 2014.

[5] S. SUROTO, Buku Pegangan Kuliah Peningkatan Kebugaran Melalui Kegiatan Senam Aerobik dan SKJ 2004. SEMARANG: FAKULTAS ISIP - UNIVERSITAS DIPONEGORO, 2004.

[6] D. Dewi, "Efektivitas Kombinasi Terapi Kukusan Labu Siam dan Senam Anti Stroke Terhadap Penurunan Tekana Darah Pada Pasien dengan Hipertensi," J. Online Mhs. Progr. Stud. Ilmu Keperawatan, vol. 1, no. 1, pp. 1-9, 2014.

[7] GLOBAL STATUS REPORT On Noncommunicable Diseases 2014. Geneva: WHO Press, 2014.

[8] S. J. K. K. Pusat Komunikasi Publik, "Hipertensi Penyebab Kematian Nomor Tiga," $2010 . \quad$ [Online]. Available: http://www.depkes.go.id/article/print/810/hipertensi-penyebab-

kematian-nomor-tiga.html. [Accessed: 01-Aug-2017].

[9] Dinas Kesehatan Kota Surabaya, "Statistik 10 Penyakit Terbanyak," 2014. [Online]. Available: http://dinkes.surabaya.go.id/portal/profil/dkk-dalam-angka/statistik-10penyakit-terbanyak/. [Accessed: 01-Aug-2017].

[10] J. E. (John E. Hall, Guyton and Hall textbook of medical physiology, 13th ed. Philadelphia: Elsevier Inc.

[11] A. D. Tilong, Waspada Penyakit-Penyakit Mematikan Tanpa Gejala Menyolok. Jakarta: Buku Biru, 2014.

[12] L. Sherwood, Human physiology: From Cells to Systems, 7th ed. Belmont: Thomson/Brooks/Cole, 2007.

[13] P. A. James et al., "2014 Evidence-Based Guideline for the Management of High Blood Pressure in Adults," JAMA, vol. 311, no. 5, p. 507 , Feb. 2014.

[14] Louis Sanford Goodman, Joel G. Hardman, Lee E. Limbird, and Alfred Goodman Gilman, Goodman \& Gilman's The Pharmacological Basis of Therapeutics. McGraw-Hill, 2001.

[15] D. R. Yuliarti, "Faktor-faktor yang Berhubungan dengan Hipertensi pada Usia Lanjut di Posbindu Kota Bogor tahun 2007," Universitas Indonesia, 2013.

[16] Suzanne C. Smeltzer, Brenda G. Bare, Janice L. Hinkle, and Kerry H. Cheever, Brunner \&amp; Suddarth's Textbook of Medical-Surgical Nursing. Philadelphia: Lippincott Williams \& WilkinsWolters Kluwer Health, 2007. 